\title{
Effect of addition of different hydrocolloids on pasting, thermal, and rheological properties of cassava starch
}

\author{
Efeito da adição de diferentes hidrocoloides sobre as propriedades de pasta, térmicas e reológicas \\ do amido de mandioca
}

\author{
Tatiana Dias LEITE ${ }^{1}$, Joel Fernando NICOLETI ${ }^{1}$, Ana Lúcia Barretto PENNA ${ }^{\text {, Célia Maria Landi FRANCO }}{ }^{1 *}$
}

\begin{abstract}
Starches and gums are hydrocolloids frequently used in food systems to provide proper texture, moisture, and water mobility. Starch-gum interaction in food systems can change the starch granule swelling and its gelatinization and rheological properties. In this study, the effect of the addition of xanthan gum (XG), sodium carboxymethyl cellulose (SCMC), and carrageenan (CAR) at the concentrations of the 0.15 , $0.25,0.35$ and $0.45 \%(\mathrm{w} / \mathrm{v})$ on the pasting, thermal, and rheological properties of cassava starch was studied. The swelling power (SP) and the scanning electron microscopy (SEM) of the starch gels were also evaluated. The results obtained showed that xanthan gum (XG) had a strong interaction with the cassava starch penetrating between starch granules causing increase in pasting viscosities, SP, storage and loss (G', and G', respectively) modulus and reduction in the setback of the starch; sodium carboxymethyl cellulose (SCMC) greatly increased the pasting viscosities, the SP, and the storage and loss (G', and G', respectively) modulus of the starch-mixtures, mainly due to its greater capacity to hold water and not due to the interaction with cassava starch. Carrageenan (CAR) did not change any of the starch properties since there was no interaction between this gum and cassava starch at the concentrations used.
\end{abstract}

Keywords: cassava starch; xanthan; carrageenan; carboxymethyl cellulose; interaction.

\section{Resumo}

Amidos e gomas são hidrocoloides frequentemente usados em sistemas alimentícios com a finalidade de fornecer textura, umidade e mobilidade de água. A interação amido-goma em sistemas alimentícios pode alterar o inchamento do grânulo de amido e as suas propriedades de gelatinização e reológicas. Neste trabalho, o efeito da adição de goma xantana (GX), carboximetilcelulose sódica (CMC) e carragena (CAR) nas concentrações de $0,15,0,25,0,35$ e $0,45 \%(\mathrm{p} / \mathrm{v})$ sobre as propriedades de pasta, térmicas e reológicas do amido de mandioca foi estudado. O Poder de inchamento (PI) e a Microscopia Eletrônica de Varredura (MEV) dos géis de amido também foram avaliados. Os resultados obtidos mostraram que a GX apresentou forte interação com o amido, penetrando entre os grânulos e provocando aumento das viscosidades de pasta, PI, G’ e G”, e redução da retrogradação do amido; CMCS aumentou as viscosidades de pasta, PI, G’ e G” das misturas, principalmente em função da sua maior capacidade de reter água, e não por causa da interação com o amido; CAR não modificou qualquer das propriedades do amido, porque não houve nenhuma interação entre essa goma e o amido de mandioca nas concentrações usadas.

Palavras-chave: amido de mandioca; xantana; carragena; carboximetil celulose; interação.

\section{Introduction}

Starch is one of the most abundant polysaccharides in nature competing only with cellulose. Its application depends on its physical and chemical properties, which vary according to the botanical source. Starch is widely used in food systems as thickening, gelling, and stabilizing agent (ELIASSON; GUDMUNDSSON, 2006), and its functionality influences or controls properties such as texture, volume, consistency, moisture retention, and shelf life of the food.

Starch granules are composed of two polysaccharides, linear amylose, and branched amylopectin molecules held together by hydrogen bonds, either directly or via hydrate bridges (SONG et al., 2006).
The most important process that happens during starch heating in water is called gelatinization. During heating, starch crystalline structure is broken and the granule absorbs water and irreversibly swells. Swollen granules, fragments from granules, and leached amylose constitute a complex system in which the granules are dispersed in a continue phase of amylose-water (HERMANSSON; SVEGMARK, 1996).

Retrogradation is basically a process of crystallization of gelatinized starch molecules that takes place due to a strong tendency of hydrogen bond formation between adjacent molecules. The association of starch molecules provides the development of a three-dimensional network that is maintained attached by crystalline areas. This network is constituted of

Received 26/1/2011

Accepted 8/5/2012 (005246)

Departamento de Engenharia e Tecnologia de Alimentos, Universidade Estadual Paulista - UNESP, Rua Cristóvão Colombo, 2265, Jardim Nazareth, CEP 15054-000,

São José do Rio Preto, SP, Brazil, e-mail: celia@ibilce.unesp.br

${ }^{*}$ Corresponding author 
starch granules and starch components in solution and cooling results in gel formation (HOOVER, 2001) that becomes sticky and can release water (syneresis).

Gelatinization and rheological properties of starches are very important for food product developments, mainly for modifying texture and stability of the products. However, native starch sometimes does not present adequate behavior due to its retrogradation tendency and syneresis, in addition to the fact that its paste is unstable to different conditions of stress such as prolonged heating, high shear, and acidic conditions (WHISTLER; BEMILLER, 1997).

The use of hydrocolloids in starch-based products, due to their functional properties (mainly stabilizing), has been a good alternative to modify starches (enhance stability, modify texture, reduce costs, control moisture and retard retrogradation) (WEBER et al., 2009; ACHAYUTHAKAN; SUPHANTHARIKA, 2008; LIU; ESKIN; CUI, 2006; SONG et al., 2006; CHAISAWANG; SUPHANTHARIKA, 2006, 2005).

Guar and locusta gums (galactomannans extracted from seed endosperm of certain plants), alginate and carrageenan (polysaccharides extracted from brown and red algae), and xanthan gum (polysaccharide produced by Xanthomonas campestris) are the most frequently used hydrocolloids in food products (MALI et al., 2003). Among the cellulose derivatives, the major example is the sodium carboxymethyl cellulose that is a water-soluble polysaccharide and has a large application in cosmetics and food as a water retention agent and a dispersion stabilizer, respectively (UENO et al., 2007), besides showing great influence on the gelatinization and retrogradation of starch (SUDHAKAR; SINGHAL; KULKARNI, 1992).

A synergic effect between hydrocolloid and starch has been observed by many researchers (BILIADERIS et al., 1997; CHAISAWANG; SUPHANTHARIKA, 2006; SONG et al. 2006; KIM; YOO, 2006), but the factors that influence this interaction are still not totally clear.

According to Biliaderis et al. (1997) and Chaisawang and Suphantharika (2006), the gelatinization characteristics of starch are directly influenced by 1) the morphological structure of gum present in the continuous phase (gel matrix) where the starch granules are involved, 2) the swelling power between the granules, and 3) the electrostatic interactions between starch granules and gum molecules. Achayuthakan and Suphantharika (2008) reported that the main difference between the guar and xanthan systems is the level of intermolecular interactions of these systems confirming the behavior of xanthan solution as a weak gel and the behavior of guar solution as an entanglement solution. According to these authors, these behaviors should be considered during the study of the effects of these gums on pasting and rheological characteristics of starch.

The objective of this study was to investigate the effect of xanthan gum (XG), carrageenan (CAR), and sodium carboxymethilcelulose (SCMC) on the pasting, thermal, and rheological properties of cassava starch.

\section{Materials and methods}

\subsection{Materials}

Cassava starch was kindly provided by Corn Products of Brazil (Jundiaí, SP, Brazil). The general composition of the cassava starch determined by AACC method (2000) was as follows: $9.99 \%$ moisture content, $0.13 \%$ protein content, $0.09 \%$ ash content, and $0.07 \%$ crude lipid content. The amylose content, determined by ISO 6647 (INTERNATIONAL..., 1987) was $18.13 \%$.

Xanthan gum (KELTROL ${ }^{\circledR}$ 521), k-carrageenean (GENULACTA ${ }^{\circledast}$ Carrageenan Type $\mathrm{k}-100$ ), and sodium carboxymethyl cellulose $\left(\mathrm{CEKOL}^{\circledR}\right.$ Cellulose Gum) were kindly supplied by CPKelco of Brazil (Limeira, SP, Brazil).

\subsection{Preparation of the starch-hydrocolloids mixtures}

The starch-hydrocolloids mixtures evaluated in this study were prepared so as to obtain dispersions with $8.0 \%(\mathrm{w} / \mathrm{v})$ of total solids. Thirteen experiments were carried out; one included cassava starch $8.0 \%(\mathrm{w} / \mathrm{v})$ without hydrocolloids and the other ones included mixtures of starch with xanthan gum (XG), sodium carboxymethyl cellulose (SCMC), and carrageenan (CAR), which were used at the concentrations of $0.15,0.25,0.35$ and $0.45 \%(\mathrm{w} / \mathrm{v})$, and the final percentage of total solids $(8.0 \%$ $\mathrm{w} / \mathrm{v}$ ) was reached by the addition of cassava starch.

The starch-XG mixture was prepared by dispersing the xanthan gum in water under agitation and heat treatment at $80{ }^{\circ} \mathrm{C}$ for complete dissolution of the gum. After that, it was cooled at $25^{\circ} \mathrm{C}$, and the starch was added, also under agitation.

The starch-SCMC and starch-CAR mixtures were prepared by dispersing the hydrocolloids in water under agitation. After complete dissolution of hydrocolloids, the starch was added under agitation.

\subsection{Pasting properties}

Pasting properties of starch with and without addition of hydrocolloids were obtained by using a Rapid Visco Analyser - RVA (Newport Scientific Instruments, Sidney, Australia). The suspensions of starch and starch-hydrocolloids $(8.0 \mathrm{w} / \mathrm{v})$ were balanced at $30^{\circ} \mathrm{C}$ for 1 minute, heated to $95^{\circ} \mathrm{C}$ at a rate of $6^{\circ} \mathrm{C} /$ minutes, held at $95^{\circ} \mathrm{C}$ for 5.5 minutes, cooled down to $50^{\circ} \mathrm{C}$ at a rate of $6{ }^{\circ} \mathrm{C} /$ minutes, and finally held at $50{ }^{\circ} \mathrm{C}$ for 2 minutes. The suspensions were stirred at $160 \mathrm{rpm}$ throughout the experiment. The analysis was performed in triplicate.

\subsection{Swelling power (SP)}

The swelling power of starch with and without hydrocolloids was determined in triplicate according to methods described by Chaisawang and Suphantharika (2005) and Mandala and Bayas (2004) with modifications. For this analysis, the total solid content of the samples was reduced by 4.8 times so that the starch would be present in excess water.

Starch dispersions $(1.67 \% \mathrm{w} / \mathrm{v})$ and starch-hydrocolloid dispersions at the concentrations of $(1.64 \% \mathrm{w} / \mathrm{v}$ starch 
and $0.031 \% \mathrm{w} / \mathrm{v}$ hydrocolloids $),(1.61 \% \mathrm{w} / \mathrm{v}$ starch and $0.052 \% \mathrm{w} / \mathrm{v}$ hydrocolloids), (1,59\% w/v starch and $0.073 \% \mathrm{w} / \mathrm{v}$ hydrocolloids) and $(1.57 \% \mathrm{w} / \mathrm{v}$ starch and $0.094 \% \mathrm{w} / \mathrm{v}$ hydrocolloids) were weighed, placed in centrifuge caped tubs, and heated in a water bath under stirring at $60-90{ }^{\circ} \mathrm{C} \pm 2{ }^{\circ} \mathrm{C}$ for 30 minutes. After heating, the tubs were immediately placed in a cooled water bath $\left(5 \pm 1^{\circ} \mathrm{C}\right)$ for 5 minutes and then centrifuged at $11.200 \mathrm{~g}$ during 15 minutes. The precipitate was separated and weighed. The supernatant was dried in an oven with air circulation at $105{ }^{\circ} \mathrm{C}$ for 24 hours and weighed. The SP was determined by the ratio between the humid and dried weight of the precipitate.

\subsection{Thermal properties}

Gelatinization properties of starch and starch-hydrocolloids mixtures were determined using a differential scanning calorimeter (DSC Pyris 1, Perkin Elmer, Norwalk, USA). Starchwater and starch-hydrocolloid mixture samples $(10 \pm 2.0 \mathrm{mg}$ ), prepared as described in item 2.2, were weighed in aluminum pans and sealed. The weighed samples were scanned at a rate of $5{ }^{\circ} \mathrm{C} /$ minutes over a temperature range of $20-90{ }^{\circ} \mathrm{C}$. An empty pan was used as a reference, and the analysis was performed in triplicate.

\subsection{Dynamic rheological behavior}

The viscoelastic behavior of the starch gel with and without hydrocolloids was determined in triplicate according to Chaisawang and Suphantharika (2006). The gels obtained from RVA were cooled at $25^{\circ} \mathrm{C}$ and then submitted to the rheological analysis using a Rheometer (AR 2000, TA Instruments, New Castle, USA). The samples were placed into the rheometer measuring system (cone and plate, $60 \mathrm{~mm}$ diameter, $2^{\circ}$ cone angle, and $0.62 \mathrm{~mm}$ gap), which was balanced at $25^{\circ} \mathrm{C}$. The experiment was performed at a constant deformation of $0.5 \%$ strain. The mechanical spectra were obtained recording storage modulus ( $\left.G^{\prime}\right)$, loss modulus ( $\left.G^{\prime \prime}\right)$, and loss tangent $\left(\tan \delta=G^{\prime \prime} / G^{\prime}\right)$ as a function of frequency $(\omega)$.

\subsection{Scanning Electron Microscopy (SEM)}

The starch gels and starch-hydrocolloid mixture gels were evaluated using a scanning electron microscope (LEO $435 \mathrm{VP}$, ZEISS, Oberkochen, German) according to the methodology described by Chaisawang and Suphantharika (2006) with modifications. In this experiment, starch dispersions $(8.0 \% \mathrm{w} / \mathrm{v})$ and the mixtures with starch $(7.75 \% \mathrm{w} / \mathrm{v})$ and hydrocolloids $(0.25 \% \mathrm{w} / \mathrm{v})$ were evaluated. The starch was dispersed into $10 \mathrm{~mL}$ of distilled water or into $10 \mathrm{~mL}$ of $0.25 \% \mathrm{w} / \mathrm{v}$ hydrocolloid solution. These dispersions were heated at $63^{\circ} \mathrm{C}$ in a water bath under minimum shear condition for 5 minutes. After that, an equal volume of $2 \% \mathrm{w} / \mathrm{v}$ of agarose solution at the same temperature was added, and then the starch-agarose mixture and the starch-hydrocolloid-agarose mixtures were immediately immersed in an ice bath. The samples were chemically fixed in $6 \%$ glutaraldeyde in $0.1 \mathrm{M}$ phosphate buffer $(\mathrm{pH} 7)$ and were post fixed overnight in $2 \%$ of osmium tetraoxide with $0.1 \mathrm{M}$ imidazole and then dehydrated through a graded series of acetone before being dried to the critical point by using $\mathrm{CO}_{2}$ After drying to the critical point, the samples were mounted in aluminum stubs and coated with gold. The images obtained in MEV were captured at a magnification of $1500 \times$ and at an accelerating voltage of $15 \mathrm{kV}$.

\subsection{Statistical analysis}

All samples were analyzed in triplicate and all data were reported as mean values and standard deviations. Statistical analysis of the results was conducted by the variance analysis, and differences among samples were determined by the Duncan's multiple range test at the 5\% level using STATISTICA 7.0 (STATSOFT, 2007).

\section{Results and discussion}

\subsection{Pasting properties}

The pasting properties of the cassava starch and starchhydrocolloid mixtures at different concentrations are shown in Table 1.

In general, the presence of SCMC was related to the highest values of viscosities, while the presence of XG was related to the highest pasting temperatures. The peak, breakdown, and final viscosities of the cassava starch increased significantly $(p<0.05)$ with the addition of SCMC and XG, and the SCMC was responsible for the largest increase. The higher the concentration of the hydrocolloids used, the higher the increase of the viscosities of the mixtures. Therefore, the peak viscosity of cassava starch increased $49.8 \%$ when the highest concentration of SCMC (0.45\%) was used, and it increased $35.7 \%$ for the same concentration of XG.

The highest value of peak viscosity found for the starchSCMC mixture indicated that the swelling rate of the cassava starch granule was not inhibited by the hydrocolloid. On the other hand, CAR addition, starting from $0.25 \%$ concentration, slightly affected the pasting viscosities of the cassava starch. Song et al. (2006) and Chaisawang and Suphantharika (2006) reported similar results when evaluating the pasting properties of mixtures of rice, and native and cationic cassava starches and different gums, among them, xanthan and guar gums. According to theses authors the higher peak, breakdown, and final viscosities of starch-gum mixtures, in comparison to starchwater, occurred because of the starch-gum system is biphasic with the gum located within the continuous phase. During gelatinization, the starch granules swell reducing the volume of the accessible phase to the gum, and then, its concentration increases resulting in a pronounced increase in the viscosity of the mixture. These authors observed highest viscosities for starch-guar gum mixtures in comparison to other gums using rice and cassava starches. According to Shi and BeMiller (2002), increases in the pasting viscosities of starch-hydrocolloid mixtures occur due to the interactions between hydrocolloids molecules and amylose and low molecular weight amylopectin molecules solubilized during starch gelatinization. 
XG addition provided great reduction in the setback of the starch-gum mixture, while SCMC and CAR addition slightly affected the retrogradation of the starch-gum mixture, independently of the concentration used. The higher the XG concentration used, the higher the setback reduction of the starch-XG mixture. It is likely that the reduction of starch setback occurs due to the competition of hydrocolloids and amylose molecules to establish an intermolecular connection during cooling, thus decreasing the quantity of amylose-amylose interactions that are fundamental to starch retrogradation. This kind of interaction seems to have occurred with higher intensity with XG.

Pasting temperature of the cassava starch-hydrocolloid mixtures increased significantly $(p<0.05)$ when compared to the cassava starch-water used as control; this effect was more pronounced when XG was used. The pasting temperature of the cassava starch-XG mixture increased $6.1^{\circ} \mathrm{C}$ when $0.45 \%$ of XG was used, while cassava starch-SCMC and cassava starch-CAR mixtures showed increases of 2.8 and $1.4^{\circ} \mathrm{C}$, respectively, when the same concentration of hydrocolloid was used. Increases in the pasting temperature were also reported by Funami et al. (2005) who evaluated the effect of the addition of $0.5 \%$ of guar gum with different molecular weights on corn starch (15\%) and by Weber et al. (2009), who studied the effect of the xanthan and guar gums on normal and waxy corn starches. Lee et al. (2002) also observed higher pasting temperatures for starch$\mathrm{CMC}$ and starch-k-carrageenan mixtures than those of sweet potato starch alone.

The addition of SCMC, independently of the concentration used, did not significantly affect $(p \leq 0.05)$ the time to peak viscosity while the addition of XG at any concentration, slightly increased this parameter. However, the CAR addition provided a significant increase $(p<0.05)$ in the peak time delaying granule swelling.

\subsection{Swelling power (SP)}

The SP of the cassava starch and the starch-hydrocolloid mixtures were determined at $60,70,80$, and $90^{\circ} \mathrm{C}$ and are shown

Table 1. Pasting properties of cassava starch with and without the addition of hydrocolloids.

\begin{tabular}{|c|c|c|c|c|c|c|c|}
\hline \multirow{2}{*}{ Samples } & \multicolumn{5}{|c|}{ Viscosity (RVU) } & \multirow{2}{*}{$\begin{array}{l}\text { Peak time } \\
\text { (minutes) }\end{array}$} & \multirow{2}{*}{$\begin{array}{c}\text { Pasting temp } \\
\left({ }^{\circ} \mathrm{C}\right)\end{array}$} \\
\hline & Peak & Through & Breakdown & Final & Setback & & \\
\hline Control & $247.7 \pm 1.2^{\mathrm{i}}$ & $82.4 \pm 0.1^{\mathrm{h}}$ & $165.3 \pm 1.3^{\mathrm{h}}$ & $153.1 \pm 0.2^{\mathrm{g}}$ & $70.7 \pm 0.2^{b}$ & $5.80 \pm 0.10^{\mathrm{h}}$ & $65.0 \pm 0.2^{\mathrm{i}}$ \\
\hline XG $0.15 \%$ & $253.5 \pm 0.7^{\text {ghi }}$ & $96.2 \pm 1.4^{\mathrm{f}}$ & $157.2 \pm 2.0^{\mathrm{i}}$ & $145.2 \pm 1.5^{\mathrm{i}}$ & $49.0 \pm 0.2^{\mathrm{e}}$ & $6.10 \pm 0.24^{\mathrm{cdef}}$ & $66.4 \pm 0.1^{\mathrm{f}}$ \\
\hline XG $0.25 \%$ & $294.6 \pm 2.9^{\mathrm{f}}$ & $105.3 \pm 0.2^{\mathrm{e}}$ & $189.3 \pm 2.6^{\mathrm{e}}$ & $149.7 \pm 0.3^{\mathrm{h}}$ & $44.3 \pm 0.1^{\mathrm{f}}$ & $6.14 \pm 0.09^{\text {cde }}$ & $68.8 \pm 0.0^{c}$ \\
\hline XG $0.35 \%$ & $326.5 \pm 3.4^{\mathrm{d}}$ & $120.1 \pm 2.2^{c}$ & $206.4 \pm 1.2^{\mathrm{d}}$ & $164.0 \pm 1.8^{\mathrm{e}}$ & $43.9 \pm 0.4^{\mathrm{fg}}$ & $6.07 \pm 0.09^{\mathrm{defg}}$ & $70.6 \pm 0.2^{\mathrm{b}}$ \\
\hline XG $0.45 \%$ & $336.2 \pm 0.7^{c}$ & $126.2 \pm 0.2^{\mathrm{b}}$ & $210.0 \pm 0.9^{\mathrm{cd}}$ & $168.3 \pm 0.2^{\mathrm{d}}$ & $42.1 \pm 0.0^{\mathrm{g}}$ & $6.14 \pm 0.09^{\text {cde }}$ & $71.1 \pm 0.0^{\mathrm{a}}$ \\
\hline SCMC $0.15 \%$ & $310.9 \pm 3.1^{\mathrm{e}}$ & $98.1 \pm 0.8^{\mathrm{f}}$ & $212.7 \pm 2.4^{c}$ & $161.4 \pm 0.9^{f}$ & $63.2 \pm 0.1^{\mathrm{d}}$ & $5.84 \pm 0.05^{\mathrm{gh}}$ & $65.6 \pm 0.0^{\mathrm{h}}$ \\
\hline SCMC $0.25 \%$ & $339.5 \pm 3.4^{c}$ & $110.7 \pm 1.7^{\mathrm{d}}$ & $228.7 \pm 1.8^{\mathrm{b}}$ & $179.3 \pm 0.1^{\mathrm{c}}$ & $68.5 \pm 1.7^{c}$ & $5.90 \pm 0.14^{\mathrm{defgh}}$ & $66.1 \pm 0.3^{\mathrm{fg}}$ \\
\hline SCMC $0.35 \%$ & $358.5 \pm 0.1^{\mathrm{b}}$ & $123.2 \pm 2.0^{\mathrm{bc}}$ & $235.3 \pm 2.0^{\mathrm{a}}$ & $192.2 \pm 0.2^{\mathrm{b}}$ & $69.1 \pm 1.8^{b c}$ & $5.87 \pm 0.00^{\mathrm{fgh}}$ & $66.8 \pm 0.1^{\mathrm{e}}$ \\
\hline SCMC $0.45 \%$ & $371.1 \pm 5.1^{\mathrm{a}}$ & $133.0 \pm 2.6^{\mathrm{a}}$ & $238.1 \pm 2.5^{\mathrm{a}}$ & $207.1 \pm 1.6^{\mathrm{a}}$ & $74.1 \pm 1.1^{\mathrm{a}}$ & $5.90 \pm 0.04^{\mathrm{defgh}}$ & $67.8 \pm 0.2^{\mathrm{d}}$ \\
\hline CAR $0.15 \%$ & $250.8 \pm 1.7^{\mathrm{hi}}$ & $81.9 \pm 0.6^{\mathrm{h}}$ & $168.9 \pm 1.1^{\mathrm{fgh}}$ & $149.7 \pm 0.5^{\mathrm{h}}$ & $67.9 \pm 0.2^{c}$ & $6.14 \pm 0.09^{\text {cde }}$ & $65.4 \pm 0.3^{\mathrm{h}}$ \\
\hline CAR $0.25 \%$ & $256.7 \pm 2.3^{\mathrm{gh}}$ & $83.5 \pm 1.4^{\mathrm{h}}$ & $173.2 \pm 1.0^{\mathrm{f}}$ & $146.7 \pm 3.1^{\mathrm{i}}$ & $63.2 \pm 1.7^{\mathrm{d}}$ & $6.33 \pm 0.00^{b c}$ & $65.5 \pm 0.1^{\mathrm{h}}$ \\
\hline CAR $0.35 \%$ & $255.7 \pm 1.2^{\mathrm{gh}}$ & $87.5 \pm 1.8^{\mathrm{g}}$ & $168.1 \pm 0.6^{\mathrm{gh}}$ & $150.5 \pm 0.6^{\mathrm{gh}}$ & $63.0 \pm 1.2^{\mathrm{d}}$ & $6.50 \pm 0.04^{\mathrm{ab}}$ & $65.9 \pm 0.1^{\mathrm{g}}$ \\
\hline CAR $0.45 \%$ & $258.1 \pm 4.1^{\mathrm{g}}$ & $87.5 \pm 0.6^{\mathrm{g}}$ & $170.6 \pm 3.5^{\mathrm{fg}}$ & $150.7 \pm 0.2^{\mathrm{gh}}$ & $63.2 \pm 0.3^{\mathrm{d}}$ & $6.64 \pm 0.05^{\mathrm{a}}$ & $66.4 \pm 0.0^{\mathrm{f}}$ \\
\hline
\end{tabular}

Each value represents mean of 3 replicates. Mean + SD. Values followed by the same letter in each column are not significantly different $(\mathrm{p}<0.05)$.

Table 2. Swelling power of cassava starch with and without the addition of hydrocolloids.

\begin{tabular}{|c|c|c|c|c|}
\hline Samples & $60^{\circ} \mathrm{C}$ & $70^{\circ} \mathrm{C}$ & $80^{\circ} \mathrm{C}$ & $90^{\circ} \mathrm{C}$ \\
\hline Control & $10.46 \pm 0.06^{\mathrm{e}}$ & $21.33 \pm 0.42^{\mathrm{e}}$ & $27.75 \pm 0.06^{\mathrm{e}}$ & $30.49 \pm 0.24^{\mathrm{gh}}$ \\
\hline XG $0.031 \%$ & $13.78 \pm 0.29^{b c}$ & $21.58 \pm 0.15^{\mathrm{de}}$ & $28.83 \pm 0.47^{\mathrm{de}}$ & $34.80 \pm 0.12^{\mathrm{d}}$ \\
\hline XG0.052\% & $13.49 \pm 0.06^{\mathrm{bcd}}$ & $21.49 \pm 0.25^{\mathrm{e}}$ & $28.10 \pm 0.74^{\mathrm{de}}$ & $36.53 \pm 0.33^{c}$ \\
\hline XG0.073\% & $13.09 \pm 0.43^{\mathrm{d}}$ & $20.84 \pm 0.15^{\mathrm{e}}$ & $30.90 \pm 0.96^{\mathrm{b}}$ & $36.21 \pm 0.83^{c}$ \\
\hline XG0.094\% & $13.18 \pm 0.26^{\mathrm{cd}}$ & $22.32 \pm 0.13^{\mathrm{d}}$ & $30.59 \pm 1.00^{\mathrm{b}}$ & $36.29 \pm 0.35^{c}$ \\
\hline SCMC 0.031\% & $10.18 \pm 0.12^{\mathrm{e}}$ & $20.95 \pm 0.18^{\mathrm{e}}$ & $29.18 \pm 0.68^{\mathrm{cd}}$ & $33.02 \pm 0.19^{\mathrm{e}}$ \\
\hline SCMC $0.052 \%$ & $13.11 \pm 0.05^{\mathrm{d}}$ & $27.65 \pm 1.15^{\mathrm{c}}$ & $30.33 \pm 0.15^{b c}$ & $40.46 \pm 0.26^{\mathrm{b}}$ \\
\hline SCMC 0.073\% & $13.32 \pm 0.83^{b c d}$ & $29.53 \pm 0.54^{\mathrm{a}}$ & $31.54 \pm 0.37^{\mathrm{b}}$ & $41.12 \pm 0.69^{\mathrm{b}}$ \\
\hline SCMC 0.094\% & $16.44 \pm 0.31^{\mathrm{a}}$ & $28.73 \pm 0.68^{b}$ & $32.92 \pm 0.35^{\mathrm{a}}$ & $42.83 \pm 0.52^{\mathrm{a}}$ \\
\hline CAR $0.031 \%$ & $13.81 \pm 0.18^{\mathrm{b}}$ & $18.73 \pm 0.22^{\mathrm{fg}}$ & $26.51 \pm 0.89^{f}$ & $28.58 \pm 0.80^{\mathrm{i}}$ \\
\hline CAR $0.052 \%$ & $13.45 \pm 0.18^{\mathrm{bcd}}$ & $18.98 \pm 0.36^{\mathrm{f}}$ & $25.55 \pm 0.02^{\mathrm{fg}}$ & $29.51 \pm 0.49^{\mathrm{hi}}$ \\
\hline CAR $0.073 \%$ & $8.70 \pm 0.28^{\mathrm{f}}$ & $18.39 \pm 0.18^{\mathrm{fg}}$ & $24.57 \pm 0.80^{\mathrm{gh}}$ & $32.39 \pm 1.07^{\mathrm{ef}}$ \\
\hline CAR 0.094\% & $8.45 \pm 0.12^{f}$ & $18.13 \pm 0.57^{\mathrm{g}}$ & $23.50 \pm 0.21^{\mathrm{h}}$ & $31.35 \pm 0.09^{\mathrm{fg}}$ \\
\hline
\end{tabular}

Each value represents mean of 3 replicates. Mean + SD. Values followed by the same letter in each column are not significantly different $(\mathrm{p}<0.05)$. 
in Table 2. The SP increased for all samples with the increase in the analysis temperature.

The addition of XG and SCMC provided a significant increase $(p<0.05)$ in the SP; such increase was more pronounced when SCMC was used at concentrations of $0.094 \%$. Similar results were found by Mandala and Bayas (2004) when they studied the effect of xanthan gum addition on wheat starch and by Chaisawang and Suphantharika (2006), who evaluated the effect of the xanthan and guar gums addition on native and cationic cassava starches. According to Mandala and Bayas (2004), XG can capture the gelatinized starch granules by keeping them close, and so it would be possible to increase the forces on these granules to ease water absorption and increase the swelling of the granules.

On the other hand, CAR did not present a uniform behavior when it was added to the starch. On the whole, at higher concentrations, this hydrocolloid caused a reduction in the SP of the mixture when compared to the starch-water system. Song et al. (2006) observed a reduction in the SP of rice starch when guar, xanthan, and Arabic gums were added to this starch, but they observed an increase in the SP when gellan gum was used. These authors justified this reduction due to the osmotic pressure generated within the continuous phase of the gum resulting from the swelling of the starch phase. Additionally, due to an increase in the viscosity of the continuous phase by the presence of hydrocolloids, the water could not penetrate into the swollen granules.

\subsection{Thermal properties}

There were no significant differences $(p<0.05)$ between gelatinization peak temperatures $(\mathrm{Tp})$ of cassava starch with or without the addition of hydrocolloids at any concentration although onset temperatures $\left(\mathrm{T}_{\mathrm{o}}\right.$ ) and complete temperatures $\left(\mathrm{T}_{c}\right)$ of starch-SCMC and starch-CAR mixtures were slightly higher than those of native starch (Table 3). Similar results were reported for Biliaderis et al. (1997) and Mali et al. (2003). Biliaderis et al. (1997) observed that the addition of different gums did not cause significant changes in the peak temperatures of corn and wheat starches. Mali et al. (2003) did not observe significant changes in the gelatinization temperatures $\left(T_{0}, T_{p}\right.$ and $\left.\mathrm{T}_{\mathrm{c}}\right)$ of yam starch suspensions $(6,0 \% \mathrm{w} / \mathrm{v})$ when guar and xanthan gums were added at the concentrations of $0.1,0.3$, and $0.5 \%$. On the other hand, Chaisawang and Suphantharika (2006) reported that the addition of xanthan and guar gums at the concentration of $0.35 \%$ in relation to starch weight increased the onset temperature of native cassava starch suspension $(6.0 \% \mathrm{w} / \mathrm{v})$. In the present study, the higher increases observed for onset and complete temperatures were of 2.2 and $1.3 \%$, respectively, when hydrocolloids were added to starch.

The enthalpy change $(\Delta \mathrm{H})$ significantly increased $(p<0.05)$ with XG addition, contrary to SCMC and CAR addition, which did not affect this parameter, independent of the concentration used. The higher the XG concentration used, the higher the $\Delta \mathrm{H}$ of the starch-XG mixture. Similar results were obtained by Biliaderis et al. (1997), Lee et al. (2002), and Mali et al. (2003).

From the RVA results, it was observed that the XG-starch mixtures presented the highest pasting temperatures (Table 1). Peak time for these mixtures increased showing a delayed tendency to swelling. These data might be related to the enthalpy increase. The $\Delta \mathrm{H}$ is related to the degree of association between the gum and starch. This association decreases the chain mobility of starch, and thus more thermal energy is needed for melting.

\subsection{Dynamic rheological behavior}

The dynamic rheological behaviors of the cassava starch and mixtures of starch and XG, SCMC, and CAR at different concentrations are shown in Figures 1 and 2.

The cassava starch and all starch-hydrocolloid mixtures showed that the storage modulus ( $\left.G^{\prime}\right)$ was higher than the loss modulus ( $\left.G^{\prime \prime}\right)$, both of them were dependent on frequency, and that G' and G" (for a same gel) did not crossover each other throughout the experiment when the frequency varied from 0.1 to $100 \mathrm{rad} / \mathrm{s}$. These results were similar to those obtained by

Table 3. Thermal properties ${ }^{\mathrm{a}}$ of cassava starch with and without the addition of hydrocolloids.

\begin{tabular}{|c|c|c|c|c|}
\hline Samples & $\mathrm{T}_{\mathrm{o}}\left({ }^{\circ} \mathrm{C}\right)$ & $\mathrm{T}_{\mathrm{p}}\left({ }^{\circ} \mathrm{C}\right)$ & $\mathrm{T}_{\mathrm{c}}\left({ }^{\circ} \mathrm{C}\right)$ & $\Delta \mathrm{H}\left({\left.\mathrm{J} . \mathrm{g}^{-1}\right)}^{-1}\right.$ \\
\hline Control & $55.95 \pm 0.50^{\mathrm{d}}$ & $63.11 \pm 0.25^{\mathrm{a}}$ & $68.96 \pm 0.08^{\mathrm{bc}}$ & $10.73 \pm 0.20^{\mathrm{d}}$ \\
\hline XG $0.15 \%$ & $56.45 \pm 0.48^{\mathrm{cd}}$ & $63.22 \pm 0.29^{a}$ & $68.99 \pm 0.26^{b c}$ & $11.60 \pm 0.70^{c}$ \\
\hline XG $0.25 \%$ & $55.91 \pm 0.20^{\mathrm{d}}$ & $62.84 \pm 0.17^{\mathrm{a}}$ & $68.60 \pm 0.11^{\mathrm{c}}$ & $12.48 \pm 0.50^{\mathrm{b}}$ \\
\hline XG $0.35 \%$ & $56.53 \pm 0.26^{\mathrm{bc}}$ & $63.27 \pm 0.35^{\mathrm{a}}$ & $69.00 \pm 0.57^{\mathrm{bc}}$ & $13.49 \pm 0.40^{\mathrm{a}}$ \\
\hline XG0.45\% & $56.36 \pm 0.26^{\mathrm{cd}}$ & $63.37 \pm 0.43^{\mathrm{a}}$ & $68.90 \pm 0.28^{\mathrm{bc}}$ & $13.93 \pm 0.50^{\mathrm{a}}$ \\
\hline SCMC $0.15 \%$ & $56.57 \pm 0.62^{\mathrm{bc}}$ & $63.06 \pm 1.00^{\mathrm{a}}$ & $69.39 \pm 0.70^{\mathrm{ab}}$ & $9.13 \pm 0.50^{\mathrm{e}}$ \\
\hline SCMC $0.25 \%$ & $56.41 \pm 0.16^{\mathrm{cd}}$ & $62.88 \pm 0.13^{\mathrm{a}}$ & $68.92 \pm 0.23^{\mathrm{bc}}$ & $10.82 \pm 0.10^{\mathrm{d}}$ \\
\hline SCMC $0.35 \%$ & $56.68 \pm 0.23^{\mathrm{abc}}$ & $63.32 \pm 0.09^{\mathrm{a}}$ & $68.79 \pm 0.23^{\mathrm{bc}}$ & $10.45 \pm 0.20^{\mathrm{d}}$ \\
\hline SCMC $0.45 \%$ & $57.19 \pm 0.23^{\mathrm{a}}$ & $63.60 \pm 0.38^{\mathrm{a}}$ & $69.05 \pm 0.35^{\mathrm{bc}}$ & $10.52 \pm 0.30^{\mathrm{d}}$ \\
\hline CAR $0.15 \%$ & $56.37 \pm 0.12^{\mathrm{cd}}$ & $62.95 \pm 0.38^{\mathrm{a}}$ & $69.01 \pm 0.28^{\mathrm{bc}}$ & $10.71 \pm 0.50^{\mathrm{d}}$ \\
\hline CAR $0.25 \%$ & $56.74 \pm 0.06^{\mathrm{abc}}$ & $63.02 \pm 0.05^{\mathrm{a}}$ & $69.43 \pm 0.14^{\mathrm{ab}}$ & $11.06 \pm 0.50^{\mathrm{cd}}$ \\
\hline CAR $0.35 \%$ & $56.68 \pm 0.03^{\mathrm{abc}}$ & $63.37 \pm 0.26^{\mathrm{a}}$ & $69.72 \pm 0.13^{\mathrm{a}}$ & $10.85 \pm 0.50^{\mathrm{d}}$ \\
\hline CAR $0.45 \%$ & $57.11 \pm 0.11^{\mathrm{ab}}$ & $63.55 \pm 0.31^{\mathrm{a}}$ & $69.85 \pm 0.39^{a}$ & $10.86 \pm 0.20^{\mathrm{d}}$ \\
\hline
\end{tabular}

${ }^{\mathrm{a}} \mathrm{To}, \mathrm{Tp}$ and $\mathrm{Tc}=$ onset, peak and complete temperature, respectively; $\Delta \mathrm{H}=$ enthalpy change. Each value represents mean of 3 replicates. Mean $+\mathrm{SD}$. Values followed by the same letter in each column are not significantly different $(\mathrm{p}<0.05)$. 

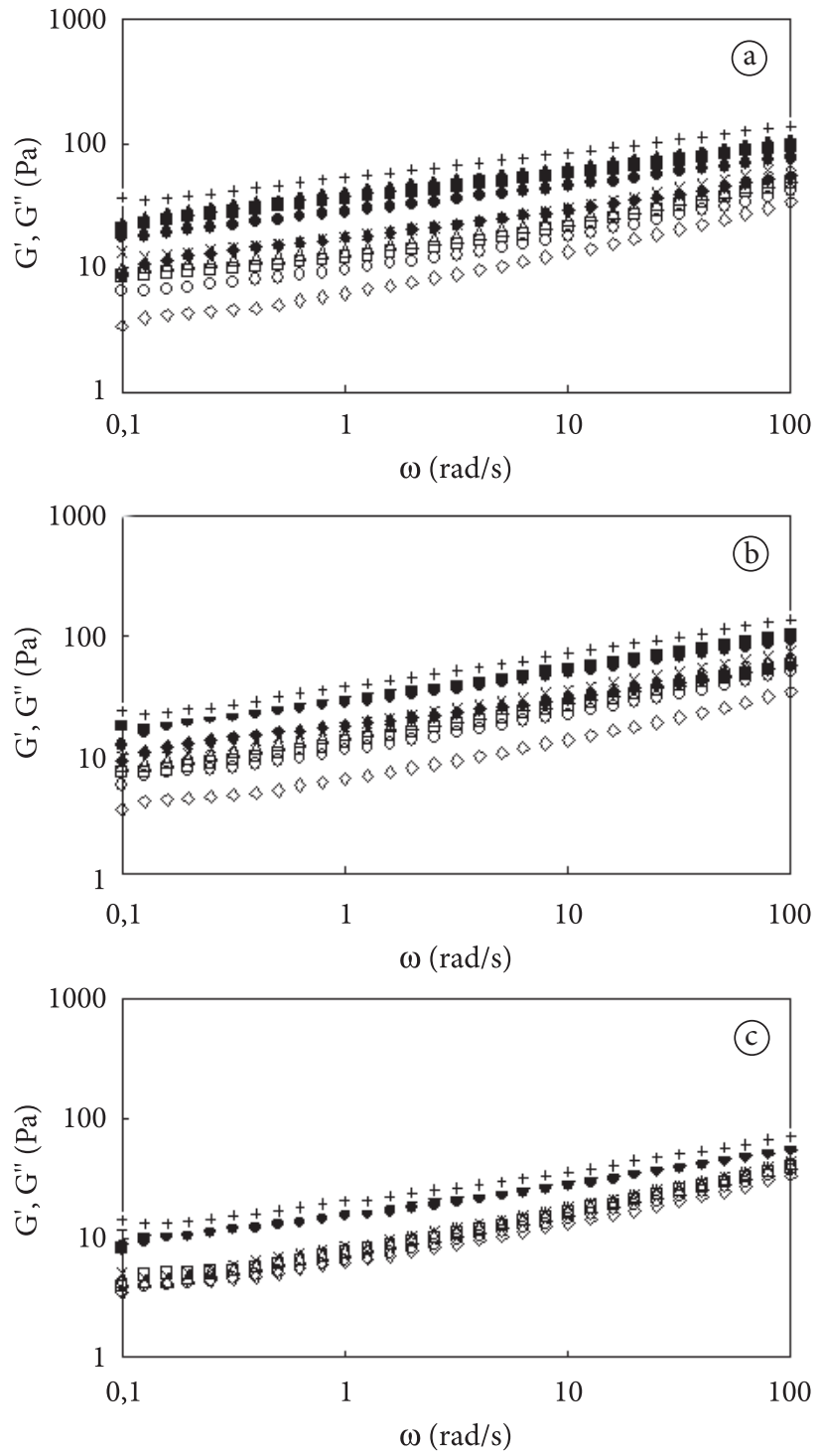

Figure 1. Dynamic mechanical spectra of the cassava starchhydrocolloid mixtures measured at $0.5 \%$ strain and $25^{\circ} \mathrm{C}$ : (a) cassava starch-XG, (b) cassava starch-SCMC, (c) cassava starch-CAR. Hydrocolloid concentrations: $(\diamond)(\bullet) 0 \%,(\circ)(\bullet) 0.15 \%$, ( $)(\bullet) 0.25 \%$, $(\triangle)(\Delta) 0.35 \%,(\times)(+) 0.45 \%$. Closed symbols and $\times$, storage modulus $\left(G^{\prime}\right)$; open symbols and + , loss modulus (G”).

Chaisawang and Suphantharika (2006) and Kim and Yoo (2006). According to Chamberlain and Rao (2000), this behavior allows classifying rheologically the gels as weak gels.

The addition of XG and SCMC to the cassava starch increased G' and G'. The higher the hydrocolloid concentration used, the higher the G' and G' (Figure 1a, b, respectively). On the other hand, the addition of CAR to the cassava starch did not cause significant differences (Figure 1c). The increase in G' and G', provided by the XG and SCMC addition to the starch, varied from 1.5 to 3.0 times as the hydrocolloid concentrations increased, in comparison to values from the native cassava
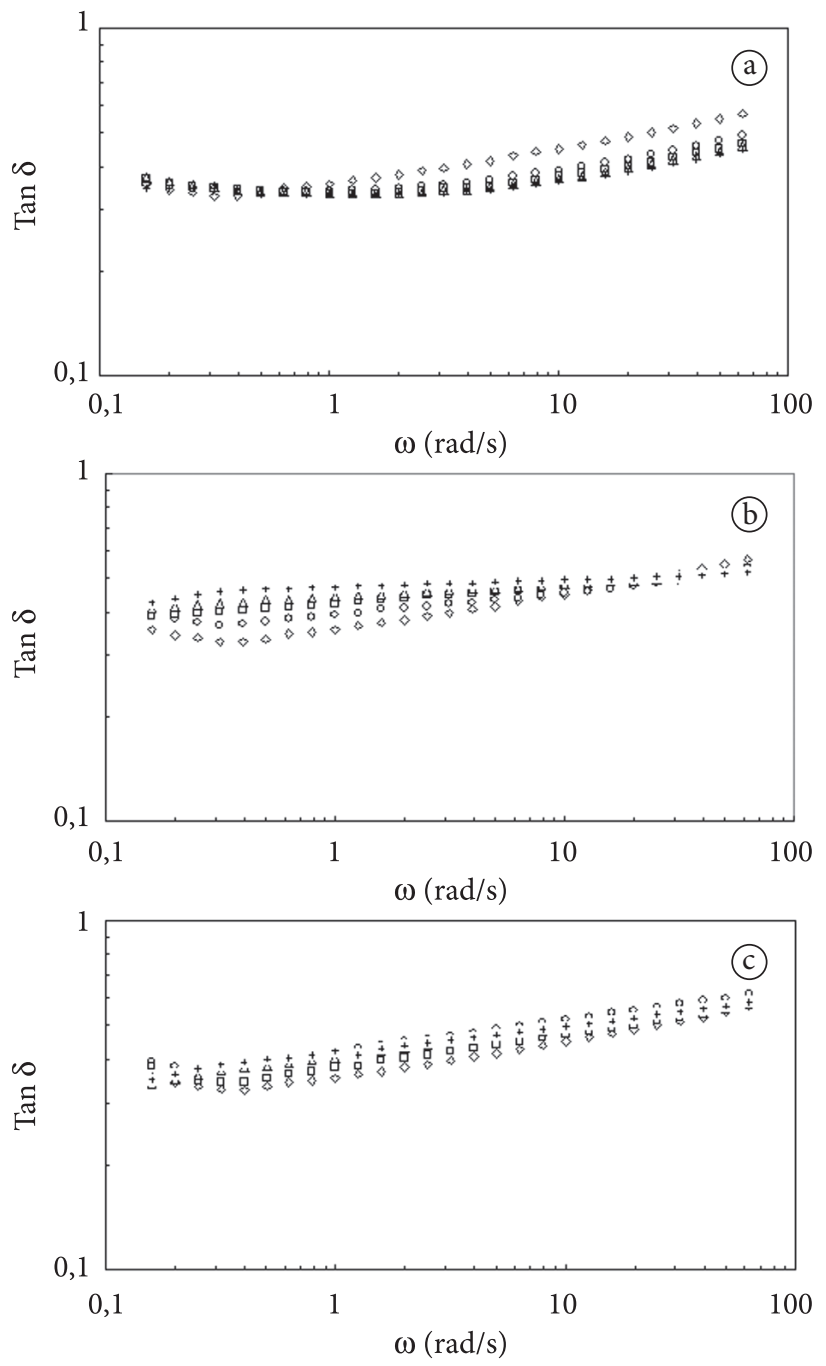

Figure 2. Dynamic mechanical loss $\tan (\tan \delta)$ of the cassava starch-hydrocolloid mixtures measured at $0.5 \%$ strain and $25^{\circ} \mathrm{C}$ : (a) cassava starch-XG, (b) cassava starch-SCMC, (c) cassava starch-CAR. Hydrocolloid concentrations: $(\diamond) 0 \%,(\circ) 0.15 \%,(\square) 0.25 \%,(\triangle) 0.35 \%$, (+) $0.45 \%$.

starch. Unlike XG and SCMC, CAR caused a slight increase in G' and G' starting from $0.25 \%$ concentration. Similar results were obtained by Ahmad and Willians (2001), Liu, Eskin and Cui (2006) and Kim and Yoo (2006), who evaluated the addition of galactomannans, yellow mustard mucilage, and xanthan gum, respectively, on different starches. Chaisawang and Suphantharika (2006) also observed that the addition of guar and xanthan gums to the cassava starch, at concentration of $0.35 \%$, increased about two times the G' and G" values of the mixtures.

The solid character $\left(G^{\prime}\right)$ of the cassava starch gel and the CAR-starch gels at the 0.35 and $0.45 \%$ concentrations were similar to the liquid character (G") of the XG-starch and SCMC-starch gels at the same concentrations, as shown in Figure 1. This behavior was also observed by Chaisawang and 
Suphantharika (2006), when evaluating the effect of xanthan and guar gums on cassava starch at $0.35 \%$ concentration.

Dynamic mechanical loss tangent $\left(\tan \delta=G^{\prime \prime} / G^{\prime}\right)$ of the cassava starch-XG mixtures was lower than $\tan \delta$ of the starchwater system (Figure 2a). The higher the XG concentration, the lower the $\tan \delta$, mainly starting from $1 \mathrm{rad} / \mathrm{s}$ frequency. A contrary effect was observed for cassava starch-SCMC and cassava starch-CAR mixtures (Figure 2b, c, respectively), i.e. the $\tan \delta$ of the starch-water system was lower than $\tan \delta$ of the starch-hydrocolloids. This effect was more pronounced up to $10 \mathrm{rad} / \mathrm{s}$ for the starch-SCMC mixtures, independent of frequency for the starch-CAR mixtures. These results indicated that the pastes from starch-XG mixtures were more structured and more solid-like than those from starch-water. On the other hand, the pastes from starch-SCMC and starch-CAR mixtures were weaker and less gel-like than those from starch-water systems. According to Achayuthakan, Suphantharika and Rao (2006) and Achayuthakan and Suphantarika (2008), the lower $\tan \delta$, the higher the stress required to break the inter-particle bonding of starch-gum thus indicating a stronger interaction between cassava starch with XG than with SCMC and CAR.

\subsection{Scanning electron microscopy}

In this analysis, the microstructures of the cassava starch granules steeped into the water or into the gum matrix (XG, SCMC, and CAR) were examined and are displayed in Figure 3. The samples were prepared at $63^{\circ} \mathrm{C}$ because this was the lowest gelatinization peak temperature obtained from DSC analysis, and it was lower than all the pasting temperatures obtained from RVA.

The cassava starch granules for all samples were clearly visualized, without any interference from the $2 \%$ agarose solution addition, which was used in this analysis to allow the starch gel fixation. In the sample of the cassava starch without hydrocolloid addition (Figure 3a), the presence of intact and swollen granules and amylose and amylopectin aggregates (AAA) leached during the initial gelatinization process, which occurred during sample preparation was observed.

In the starch-XG mixture (Figure 3b), besides the intact and swollen granules and AAA, it was also possible to observe an entanglement (Figure $3 \mathrm{~b} \rightarrow$ ) between the gum and the cassava starch, as if the gum were penetrating between the swollen granules and the AAA. Mandala, Palogou and Kostaropoulos (2002) evaluated the influence of preparation and storage
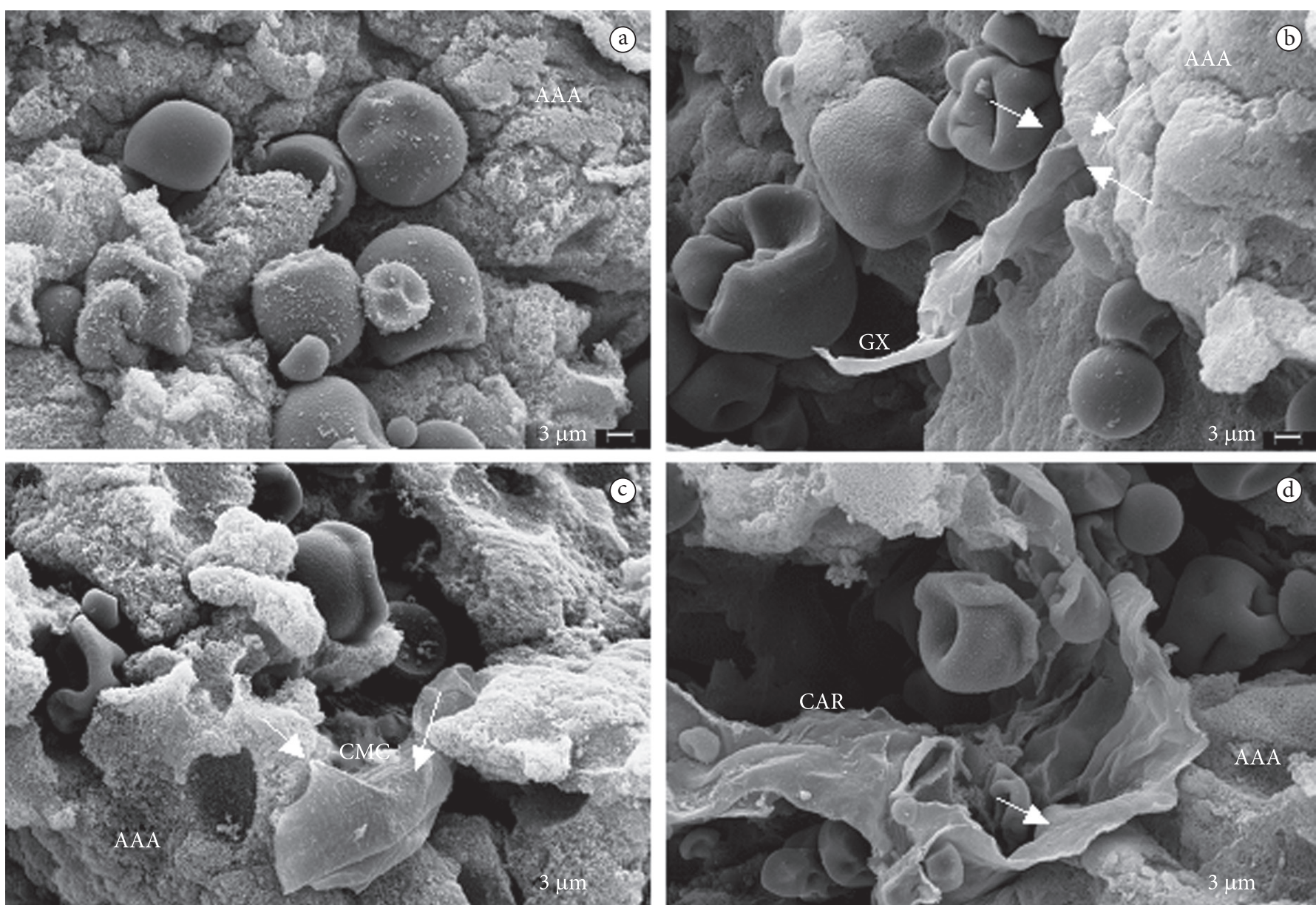

Figure 3. Scanning electron micrographs of the cassava starch and cassava starch-hydrocolloid mixtures: (a) cassava starch, (b) cassava starch-0.25\% XG, (c) cassava starch-0.25\% SCMC, (d) cassava starch-0.25\% CAR. AAA: amylose and amylopectin aggregates; (1500×; bar: $3 \mu \mathrm{m})$. 
conditions on the texture of potato starch-xanthan gum mixtures. They reported that the xanthan gum could wrap the starch granules and form a network around the granules acting as a physical protection agent against the granule integrity loss when a force was applied.

An entanglement between SCMC and the starch was also observed (Figure $3 c \rightarrow$ ); however this interaction seemed to be lower than that of cassava starch-XG. In this case, it was possible to observe that the SCMC was thicker than XG.

Figure $3 \mathrm{~d}$ shows that the CAR was dispersed in the aqueous medium containing cassava starch like a thin sheet suggesting no interaction between the gum and the cassava starch.

From results obtained in this study, it was possible to observe that the cassava starch-XG mixtures had the lowest $\tan \delta$ and increases in the G' and G', swelling power, peak, breakdown, and final viscosities. There was also a pronounced reduction in the setback. There was an increase in the pasting temperatures and enthalpy changes when the gum concentration was increased. Finally, it was observed that the gum penetrated between the swollen granules and amylose and amylopectin aggregates in the gel matrix. These data suggest that there was an interaction between starch and XG, which probably occurred due to the hydrogen bond formation between the gum and the amylose chains leached during gelatinization making the amylose unavailable for rearrangement during cooling of the paste. This interaction also made difficult the mobility of the starch polymers increasing the enthalpy during gelatinization.

The cassava starch-SCMC mixture showed increases in the pasting viscosities, swelling power, and G' and G' besides displaying a thick appearance, probably due to its high capacity of water retention competing with starch in holding water.

Finally, CAR practically did not affect the functional and rheological properties of starch and showed itself as a thin sheet dispersed in the gel matrix suggesting no interaction with the starch at the concentrations used in this work.

\section{Conclusions}

Based on the results of RVA, SP, DSC, and rheological properties, it is possible to suggest that the behavior of the starch-hydrocolloid mixture is dependent on the structure and molecular mass of the hydrocolloids and their concentration. However, in the present study, there seems to be two kinds of associations between cassava starch and hydrocolloids: association of the hydrocolloid with swollen starch granules or leached amylose chains in the paste, probably by the formation of hydrogen bonds, as it seems to have occurred with starchXG mixtures, and the competition of the hydrocolloid with starch for water as it seems to have occurred with starch-SCMC mixtures. On the other hand, none of these associations was observed for starch-CAR mixtures.

\section{Acknowledgements}

The authors are grateful to the CPKelco of Brazil and the Corn Products of Brazil for supplying the samples.

\section{References}

ACHAYUTHAKAN, P.; SUPHANTHARIKA, M. Pasting and rheological properties of waxy corn starch as affected by guar gum and xanthan gum. Carbohydrate Polymers, v. 71, n. 1, p. 9-17, 2008. http://dx.doi.org/10.1016/j.carbpol.2007.05.006

ACHAYUTHAKAN, P.; SUPHANTHARIKA, M.; RAO, M. A. Yield stress components of waxy corn starch-xanthan mixtures: Effect of xanthan concentration and different starches. Carbohydrate Polymers, v. 65, n. 4, p. 469-478, 2006.

AHMAD, F. B.; WILLIANS, P. A. Effect of galactomannans on the thermal and rheological properties of sago starch. Journal of Agricultural and Food Chemistry, v. 49, n. 3, p. 1578-1586, 2001. http://dx.doi.org/10.1021/jf000744w

BILIADERIS, C. G. et al. Effect of hydrocolloids on gelatinization and structure formation in concentrated waxy maize and wheat starch gels. Starch/Stärke, v. 49, n. 7-8, p. 278-283, 1997. http://dx.doi. org/10.1002/star.19970490706

CHAISAWANG, M.; SUPHANTHARIKA, M. Pasting and rheological properties of native and anionic tapioca starches as modified by guar gum and xanthan gum. Food Hydrocolloids, v. 20, n. 5, p. 641-649, 2006. http://dx.doi.org/10.1016/j.foodhyd.2005.06.003

CHAISAWANG, M.; SUPHANTHARIKA, M. Effects of guar gum and xanthan gum additions on physical and rheological properties of cationic tapioca starch. Carbohydrate Polymers, v. 61, n. 3, p. 288-295, 2005. http://dx.doi.org/10.1016/j.carbpol.2005.04.002

CHAMBERLAIN, E. K.; RAO, M. A. Effect of concentration on rheological properties of acid-hydrolyzed amylopectin solutions. Food Hidrocolloids, v. 14, n. 2, p. 163-171, 2000. http://dx.doi. org/10.1016/S0268-005X(99)00063-6

ELIASSON, A. C.; GUDMUNDSSON, M. Starch: Physicochemical and functional aspects. In: Eliasson, A-C (Ed). Carbohydrates in food. 2nd ed. Boca Raton: CRC Press, 2006. p. 391-469.

FUNAMI, T. et al. Food hydrocolloids control the gelatinization and retrogradation behavior of starch. 2a Functions of guar gums with different molecular weights on the gelatinization behavior of corn starch. Food Hydrocolloids, v. 19, n. 1, p. 15-24, 2005. http://dx.doi. org/10.1016/j.foodhyd.2004.04.008

HERMANSSON, A. M.; SVEGMARK, K. Developments in the understanding of starch functionality. Trends in Food Science and Technology, v. 7, p. 345-353, 1996. http://dx.doi.org/10.1016/ S0924-2244(96)10036-4

HOOVER, R. Composition, molecular structure, and physicochemical properties of tuber and root starches: a review. Carbohydrate Polymers, v. 45, n. 3, p. 253-267, 2001. http://dx.doi.org/10.1016/ S0144-8617(00)00260-5

I N T E R N A T I O N A L O R G A N I Z A T I O N F O R STANDARDIZATION - ISO. ISO 6647: Riz- détermination de la teneur en amylose. ISO, 1987. 5 p.

KIM, C.; YOO, B. Rheological properties of rice starch-xanthan gum mixtures. Journal of Food Engineering, v. 75, n. 1, p. 120-128, 2006. http://dx.doi.org/10.1016/j.jfoodeng.2005.04.002

LEE, M. H. et al. Freeze-thaw stabilization of sweet potato starch gel by polysaccharide gums. Food Hydrocolloids, v. 16, n. 4, p. 345-352, 2002. http://dx.doi.org/10.1016/S0268-005X(01)00107-2

LIU, H.; ESKIN, N. A. M.; CUI, S. W. Effects of yellow mustard mucilage on functional and rheological properties of buckwheat and pea starches. Food Chemistry, v. 95, n. 1, p. 83-93, 2006. http://dx.doi. org/10.1016/j.foodchem.2004.12.027 
MALI, S. et al. Influence of $\mathrm{pH}$ and hydrocolloids on yam (Dioscorea alata) starch pastes stability. Lebensmittel Wissenschaft und Technologie, v. 36, n. 5, p. 475-481, 2003. http://dx.doi.org/10.1016/ S0023-6438(03)00043-4

MANDALA, I. G.; BAYAS, E. Xanthan effect on swelling, solubility and viscosity of wheat starch dispersions. Food Hydrocolloids, v. 18, n. 2, p. 191-201, 2004. http://dx.doi.org/10.1016/S0268005X(03)00064-X

MANDALA, I. G.; PAlOGOU, E. D.; KOSTAROPOUlOS, A. E. Influence of preparation and storage conditions on texture of xanthan-starch mixtures. Journal of Food Engineering, v. 53, n. 1, p. 27-38, 2002. http://dx.doi.org/10.1016/S0260-8774(01)00136-4

SHI, X.; BEMILLER, J. N. Effects of food gums on viscosities of starch suspensions during pasting. Carbohydrate Polymers, v. 50, n. 1, p. 7-18, 2002. http://dx.doi.org/10.1016/S0144-8617(01)00369-1
SONG, J. Y. et al. Pasting properties of non-waxy rice starchhydrocolloid mixtures. Starch/Stärke, v. 58, n. 5, p. 223-230, 2006. http://dx.doi.org/10.1002/star.200500459

SUDHAKAR, V.; SINGHAL, R. S.; KULKARNI, P. R. Starch-gum interactions: Formulations and functionality using amaranth/corn and CMC. Starch/Stärke, v. 44, n. 10, p. 369-374, 1992.

UENO, T. et al. Conformational changes in single carboxymethylcellulose chains on a highly oriented pyrolytic graphite surface under different salt conditions. Carbohydrate Research, v. 342, n. 7, p. 954-960, 2007. http://dx.doi.org/10.1016/j.carres.2007.01.017

WEBER, F. H. et al. Interaction of guar and xanthan gums with starch in the gels obtained from normal, waxy and high amylose corn starches. Starch/Starke, v. 61, n. 1, p. 28-34, 2009. http://dx.doi. org/10.1002/star.200700655

WHISTLER, R. L.; BEMILLER, J. N. Carbohydrate chemistry for food scientists. St Paul: Eagan Press, 1997. 241 p. 